\title{
Rød, hvid og brun terror
}

\section{af Henrik Stevnsborg}

De sønderjyske Landsdele var i tiden op til 2. verdenskrig arbejdsmark for tyske efterretningsfolk, og også sovjetrussiske agenter stejfede området. Ud fra en enkelt sag i den sønderjyske politiadjudants arkiv belyser lektor Henrik Stevnsborg, Københavns Universitet, kommunistlederen Béla Kuns aktiviteter i så henseende. Det fortsat kontroversielle spørgsmål om samarbejdet mellem dansk og tysk politi i 1930erne bliver ligeledes berørt.

Det var sommeren 1966, og det var 2.g. Vi terpede. En af de bøger, vi skulle op i, var "Gads historie for gymnasier og seminarier«. Fra den husker jeg en enkelt løsreven sætning. Den lød: »På den røde terror fulgte nu en hvid«.

Denne knappe sentens henviser til nogle af de blodigste begivenheder i Ungarns nyere historie. ${ }^{1}$ Under 1. verdenskrig løsrev Ungarn sig fra Østrig, og det østrig-ungarske dobbeltmonarki under huset Habsburg ophørte med at eksistere i 1918. Alligevel betragtede krigens allierede sejrherrer Ungarn som en taber på lige fod med Østrig. De allierede, og ikke mindst Frankrig, ønskede derfor, at Ungarn skulle afgive store landområder til nabostaterne. Det var ved dén lejlighed, det nu hedengangne Jugoslavien blev skabt. Men også Tjekkoslovakiet og Rumænien stillede territoriale krav - og proklamerede, at de om nødvendigt ville se dem opfyldt med våben $\mathrm{i}$ hånd.

Den udenrigspolitiske krise var med andre ord akut, da kommunisterne greb magten og den 21. marts 1919 udråbte Ungarn til en sovjetrepublik. ${ }^{2} 133$ dage varede dette første kommunistiske eksperiment i Ungarn, hvis politiske politi kopierede den sovjetrussiske Tjekas berygtede metoder: gidseltagninger, torturkamre og præventive anholdelser i de årle morgentimer. Hertil kom specialstyrker som Lenin fiúk, »Lenins Drenge«, et straffe- og rekvisitionskorps, der turede landet rundt for at kidnappe kapitalister og tvinge modvillige bønder til at aflevere fødevarer. Det antages, at omkring 500 mennesker mistede livet som kontrarevolutionære under den røde terror. ${ }^{3}$

I april 1919 gjorde rumænske og tjekkiske styrker alvor af truslerne og gik til angreb. I august var kampagnen slut, og de sejrende rumænske tropper kunne marchere ind i Budapest. På dét tidspunkt havde Sovjet-Ungarns faktiske hersker, kommissæren for udenrigsanliggender Béla Kun, bragt sig i sikkerhed. Béla Kun, der var journalist fra Transsylvanien, flygtede til Østrig, hvor han blev forbigående interneret. Senere kom han til Moskva. ${ }^{4}$

Da kommuniststyret faldt, var vejen banet for de hvide, d.v.s. godsejerne og 
embedsmændene. Med admiral Miklós Horthy som øverste chef iværksatte et virvar af private hære og frikorps en bølge af hvid terror. 100.000 ungarere flygtede; 75.000 blev interneret; antallet af henrettede opgives både i hundreder og i tusinder - og er altså omgærdet med største usikkerhed. ${ }^{5}$ Til gengæld står det fast, at Horthy kronede de anti-kommunistiske udrensninger med at lade sig vælge til rigsforstander 1. marts 1920, samt at admiralen og hans junta helt frem til 1944 regerede Ungarn som en anden bananrepublik.

\section{Kommunistiske terrorgrupper}

Den 3. maj 1935 skrev Sønderborg politi rapport på baggrund af underhåndsinformationer fra en ansat ved Geheime Staatspolizei i Flensborg - der igen havde sine oplysninger fra en kommunistisk meddeler i Danmark ${ }^{6}$. Rapporten vedrører bl.a. Béla Kun. Den hører til en sag, der bærer journalnummer $969 \mathrm{i}$ det sønderjyske politiadjudantarkiv, og som på flere måder er interessant. For det første fordi den giver anledning til at rekapitulere Béla Kuns skæbne, der i mangt og meget var typisk for en topkommunist $i$ årene mellem de to verdenskrige. Og for det andet fordi den rammer direkte ind i spørgsmålet om dansk politis samarbejde med tysk politi i 30'erne.

Af politirapporten fremgik, at Béla Kun i dagene omkring 1. maj samme år havde været i Flensborg. Han var indrejst fra Danmark og var returneret hertil. Formålet var at organisere kommunistiske terrorgrupper i en række af de lande, der grænsede op til Tyskland, bl.a. Polen og Tjekkoslovakiet - samt Danmark. Béla Kuns underjordiske organisationsarbejde koordineredes med tilsvarende aktiviteter i Tyskland. Derfor lynvisitten i Flensborg.

Om terrorgrupperne hedder det i Sønderborg politis rapport, at de "på et givent tidspunkt (skulle) kunne foretage omfattende sabotagehandlinger over for bygninger og foretagender af særlig betydning ... hvorefter organisationen vil udnytte den derved skabte panikstemning til at "vælte systemet over ende««. Béla Kun selv omtales indforstået som »den kendte kommunistagitator «. Ankommet til Moskva i 1919 blev han nemlig en af Lenins betroede medarbejdere. Béla Kun fungerede som militærguvernør på Krim, han arrangerede arbejderdemonstrationer i Tyskland i 1921, og han blev ansvarlig for udgivelsen af Lenins værker på fremmede sprog. Hovedindsatsen i Kuns sovjetrussiske eksil faldt dog inden for arbejderbevægelsens 3. Internationale, den kommunistiske internationale - den, der almindeligvis kendes som Komintern.

Mellemkrigstidens totalitære systemer havde en svaghed for eufemistiske forkortelser. Komintern betegnede en sammenslutning af de nationale kommunistpartier til eet globalt kommunistisk parti. ${ }^{7}$ På Kominterns verdenskon- 


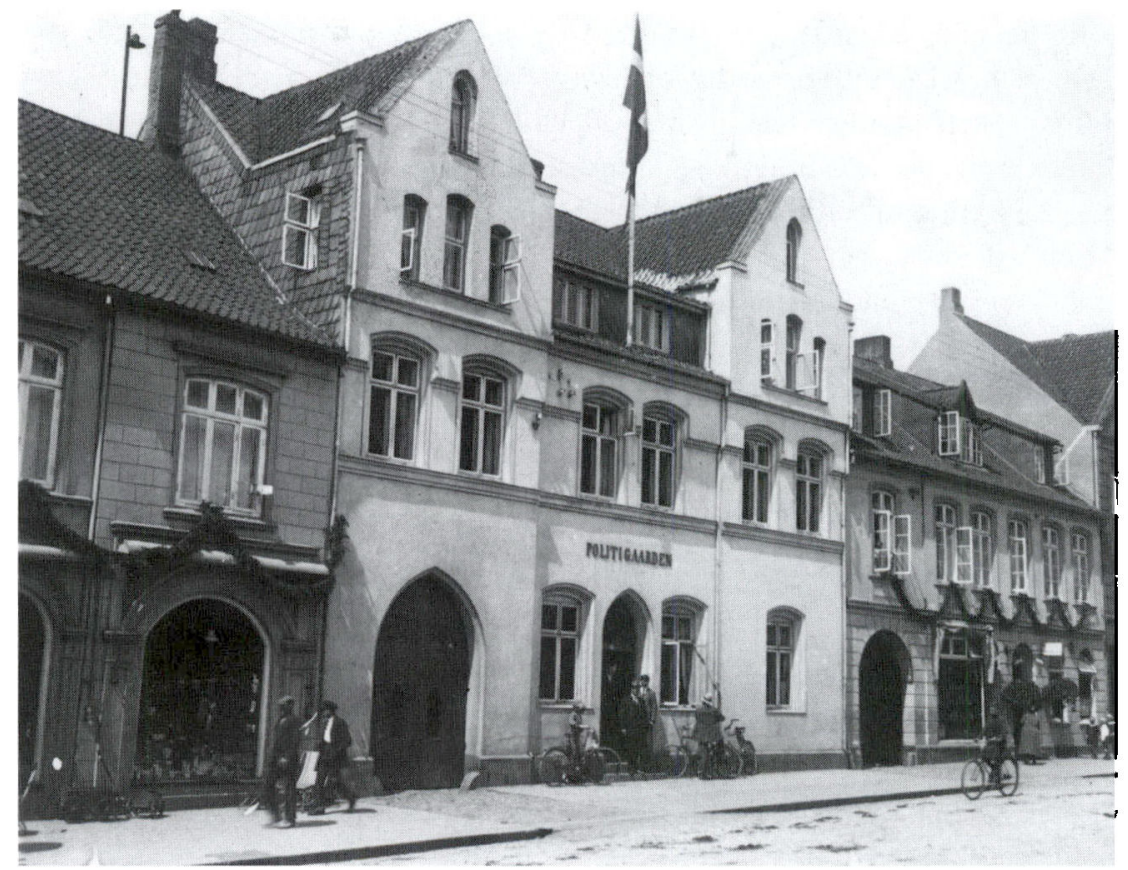

Politigården i Sonderborg i 1930. Her foregik den danske del af efterforskningen i 1935 mod Béla Kuns internationale terroristvirksomhed. Foto: Lokalhistorisk Arkiv Sonderborg.

gresser i 1921 og 1928 valgtes Béla Kun til præsidiet for det højeste organ, eksekutivkomiteen, EKKI. I det daglige arbejdede han i Kominterns diverse sektioner, herunder i Den vesteuropæiske Sektion, i Den kinesiske Sektion og i Balkansektionen. Hovedsædet lå i Moskva, og efterhånden udviklede Internationalen sig til et redskab for Sovjetunionens udenrigspolitik. Agitation var et middel i den politiske kamp; men Komintern veg ikke tilbage for brugen af hverken »terrorgrupper «, »sabotage« eller "panik « for at nå sine mål: proletariatets diktatur, afskaffelse af klasserne, virkeliggørelse af socialismen og indførelsen af det kommunistiske verdenssamfund. Komintern ville, kort sagt, verdensrevolutionen.

\section{Sabotage mod Lillebæltsbroen?}

I dette lys lod oplysningerne fra det tyske politi om Béla Kun sig ikke uden videre affærdige. Det danske politi så da også udmærket logikken i, at Kun og Komintern opererede i Danmark, eftersom »Danmark på grund af sin særlige 
beliggenhed ved indgangen til Østersøen og som grænseland til Tyskland vil være et af de vigtigste steder at have fodfæste $\mathrm{i}$ en sovjetrussisk-tysk konflikt ${ }^{8}$ - den konflikt, der jo blev til virkelighed under 2. verdenskrig. Mest alarmerende var dog oplysningen om, at Béla Kun agtede at lade sine sabotører gå $\mathrm{i}$ aktion allerede 11 dage senere, når Lillebæltsbroen skulle indvies den 14. maj 1935.

På dén baggrund valgte politimesteren i Sønderborg at sende to kriminalbetjente officielt til Flensborg for at indhente supplerende oplysninger. Resultatet af denne henvendelse blev opsummeret i en politirapport den 9. maj 1935. Heraf fremgår, at Béla Kun siden 1933 havde været eftersøgt i Det tredie Rige for terrorisme; at Gestapo nærede stærk mistanke om, at han p.t. opholdt sig illegalt i København; samt at han, såvidt man vidste, rejste under mindst fire forskellige dæknavne med et tilsvarende antal falske pas. ${ }^{9}$

Sønderborg politi tog desuden direkte, men meget diskret, kontakt til den ansatte ved det hemmelige tyske statspoliti, der oprindelig havde lækket meddelelsen om Béla Kun og hans samfundsomvæltende aktiviteter. Den pågældende tyske politimand tegnede da billedet af en kommunistleder, der uafladeligt var på farten. Så i Berlin. Så i München. Og så i Flensborg. Forklædningerne vekslede. Ifølge Sønderborg politis rapport af 12. maj 1935, hvori disse underhåndsoplysninger siden blev indført, rejste Kun »dels som kvinde, dels som en forretningsmand med sekretær, dels også som en svagelig person, der er på sygerejse». Men bag »kvinden«, »forretningsmanden« og "reconvalescenten« skjulte sig en højst martialsk skikkelse med »særlig interesse for våben- og ammunitionsdepoter« og med et følge af »militæruddannede medhjælpere ${ }^{10}$.

De sidstnæunte, der som Béla Kun selv støttedes med sovjetrussiske pengemidler, skulle selvsagt bistå ved opstillingen af de famøse terrorgrupper. Af sådanne skulle der eksistere syv, og disse skulle »gennemsnitligt hver bestå af 12 personer, som naturligvis er særlig udsøgte og betroede folk, der er rede til at sætte livet ind for deres ideers gennemførelse (fantaster). Organisationen inden for grupperne er efter samme mønster og opbygning som tidligere $i$ Zar-tidens Rusland de anarkistisk-nihilistiske terrorgrupper. Medlemmmerne bliver uddannet $\mathrm{i}$ betjening af sprængstoffer samt fremstilling af sprænglegemer. Desuden bliver de gjort bekendt med disse tings slagkraft og virkeevne samt deres anvendelsesmetoder over for personer og institutioner. Desuden $i$ iværksættelse af strejker og standsninger, ophidselse af folkemængder til frembringelse af tumulter af enhver art o.s.v., men altid på en sådan måde, at de selv forsvinder i baggrunden «. ${ }^{11}$

Såvidt 12. maj-rapporten. Som bekendt blev Lillebæltsbroen indviet to dage senere under stor festivitas. 20.000 tilskuere så Kongen køre forbi i et af DSB's 
funklende nye lyntog. Færgehorn tudede. 25 kampfly drønede i formation over broen. Og både Fredericia og Middelfart bød til asfaltbal om aftenen. ${ }^{12}$ Men bombesprængninger var der ingen af. Og der blev ikke gjort forsøg på at "vælte systemet over ende« den 14. maj 1935.

Naturligvis kan der have været et element af desinformation i Gestapos oplysninger; man kan have overdrevet Béla Kuns farlighed for at animere dansk politi til at støve ham op. En anden forklaring kunne være, at politiledelsen faktisk tog sine forholdsregler $\mathrm{i}$ forbindelse med Lillebæitsbroens indvielse. Fra den særlige sønderjyske udrykningstjeneste, kaldet 100-mandsholdet, blev udkommanderet militært trænede og tungt bevæbnede politibetjente. ${ }^{13}$ Over for dette magtopbud kan Béla Kun have foretrukket at afblæse aktionen. En tredie forklaring kunne være, at Kun midt i maj 1935 måtte halse til Moskva for at forsvare sig og sin politik. Traditionelt havde Komintern - og Kun - udskreget socialdemokraterne som kommunismens hovedfjende. Det rivaliserende arbejderparti var "socialfascistisk «, som det hed. Men efter nazisternes magtovertagelse og det påfølgende forbud mod kommunistpartiet i Tyskland, bredte sig en erkendelse af, at fjenden i stedet skulle søges i diktaturerne. Ergo burde alle gode kræfter, inclusive de socialdemokratiske, forenes i kampen mod de sorte fascister og de brune nazister. Denne »folkefrontsstrategi« var hovedemnet på Kominterns 7. verdenskongres, hvortil de praktiske forberedelser påbegyndtes netop medio maj 1935. ${ }^{14}$

Selve kongressen åbnede i Moskva den 25.juli 1935. 513 delegerede fra 76 kommunistpartier vedtog her den nye politik og hængte samtidig modstanderne af folkefrontslinien ud for "sekterisme» eller whøjre-opportunisme«. Kongressen undlod, meget sigende, at genvælge Béla Kun til sit præsidium. Som en ledende talsmand for den linie, der etiketterede socialdemokrater som socialfascister - og som den, der altid brutalt havde slået ned på alle forsøg på afvigelser fra denne linie - tilhørte Béla Kun nu det tabende parti.

Hans sag hos dansk politi afrundes da også brat med et par dødsannoncer fra august 1939. »Ungarns røde hersker" (avisen "Socialdemokraten«) og "Menneskedyret Béla Kun« (det nationalsocialistiske »Fædrelandet«) meldes skudt i et fængsel i Moskva. I lighed med så mange andre ledende kommunister faldt Béla Kun som offer for Stalins udrensninger. I foråret 1937 fik han ordre om at give møde for Kominterns præsidium, hvor han blev anklaget for ungarsk nationalisme og for manglende respekt for Stalins høje person. Siden så man ham aldrig. I februar 1956 blev han imidlertid rehabiliteret, og i 1964 fik enken Irén symbolsk udleveret Béla Kuns mange sovjetrussiske ordener og medaljer. 


\section{Kidnapninger og risiko for $\mathrm{krig}$}

I sagen om Béla Kun blev der som nævnt samarbejdet mellem dansk og tysk politi. Men fra dansk side gik man alt andet end blåøjet ind i dette samarbejde. En politirapport fra 15. marts 1935 dokumenterer, at samarbejdspartneren blev betragtet med yderste skepsis. Det hemmelige statspoliti i Flensborg havde ifølge rapporten foretaget efterforskning på dansk territorium - på egen hånd. ${ }^{15}$ Den efterfølgende tyske forsikring lød, at dansk suverænitet ikke var blevet krænket; der var blot tale om et par toldere, som havde anstillet sonderende undersøgelser om påståede natlige transaktioner mellem danske og tyske fiskere. Det troede Sønderborg politi ikke på. Under hånden blev det da også fra tysk hold indrømmet, at »tolderne« var Gestapomænd, og at deres egentlige bytte var kommunistlederen Béla Kun. Herefter blev der i en udenrigsministeriel note protesteret officielt over for Det tredie Rige.

Berlin bestred i $\sin$ verbalnote ${ }^{16}$ ikke, at medarbejdere fra Geheime Staatspolizei i Flensborg undertiden havde opholdt sig i Danmark. Men med en enkelt undtagelse havde deres ærinde altid været private familiebesøg nord for grænsen. Undtagelsen var kriminalsekretær Bruns, der havde været heroppe for at føle en dansk kommunist på tænderne - nemlig den meddeler, som oprindelig havde henledt opmærksomheden på Béla Kun. At kriminalsekretæren $\mathrm{i}$ den anledning udelukkende skulle have ført "rent informatoriske samtaler « med sin meddeler var ikke en forklaring, der tilfredsstillede det danske politi. Snarere ville man antage, at Bruns' hemmelighedsfulde Danmarksbesøg kunne stå $\mathrm{i}$ forbindelse med tyske planer om at kidnappe Béla Kun. Som chefen for det danske grænsegendarmeri, oberstløjtnant Paludan-Müller, i dén forbindelse bramfrit udtrykte sig: »Jo mere jeg tænker over bortførelse fra Danmark til Tyskland, jo klarere ser jeg, hvor pærelet, det er at udføre «. ${ }^{17}$

To aktuelle episoder betød, at sådanne bortførelsesplaner ikke straks kunne henvises til fantasiens overdrev. 30. april 1935 måtte Tjekkoslovakiet nedlægge protest over for Berlin $i$ anledning af, at den tyske politiske flygtning Joseph Lampesberger var blevet lokket ud af landet og mishandlet og arresteret ved en tysk grænsestation. Og i Schweiz blev en journalist ved navn Berthold Jacob den 28. marts 1935 med magt bragt til Tyskland af nazistiske provokatører og ufortøvet anholdt. Først i løbet af sommeren 1935 blev begge de kidnappede påny sat på fri fod. ${ }^{18}$

At kidnapninger indgik $\mathrm{i}$ et stormagtsspil, som indebar risikoen for krig, var dansk politi opmærksom på. Og politiet var opmærksom på, at også vi kunne blive inddraget $\mathrm{i}$ krigen. I sagen om Béla Kun er således indlagt en politirapport, dateret 9. april 1935, af hvilken fremgår, at en dansk politimand et par dage forinden havde været vidne til et foruroligende syn: „Rigsværnet 
fra Flensborg havde opstillet lette haubitzere i udkanten af skoven og på landevejen Flensborg-Aabenraa; der blev foretaget opmålinger og opstilling af skyts med retning mod Danmark. Det er første gang siden Genforeningen, at det tyske militær har afholdt sådanne øvelser i så umiddelbar nærhed af grænsen ${ }^{19}$

De danske politimyndigheder var ingenlunde blinde for, at den røde terror østfra kun var een af truslerne mod demokratiet. Også sydfra truede terror den brune terror!

\section{NOTER}

1. F.eks. Klaus-Detlev Grothusen (red.), Südosteuropa-Handbuch 5. Ungarn, 1987. Jörg K. Hoensch: A History of Modern Hungary 1867-1987, 1988. Péter Hanák (red.): Die Geschichte Ungarns. Von den Anfängen bis zur Gegenwart, 1988. Peter F. Sugar, Péter Hanák og Tibor Frank (red.): A History of Hungary, 1990.

2. Rudolf Tökés: Béla Kun and the Hungarian Soviet Republic, 1967.

3. Tökés, s. $156 \mathrm{ff}$ og 214, n. 5. Jfr. Andrew C. Janos: The Politics of Backwardness in Hungary, 1982 , s. 197 , n. 144.

4. Om Béla Kuns liv og levned se f.eks. Robert A.Gorman (red.): Biographical Dictionary of Marxism, 1986, s. 172-174. Branko Lazitch in collaboration with Milorad M. Drahkovitch (red.): Biographical Dictionary of the Comintern. New, Revised, and Expanded Edition, 1986, s. 239241.

5. Tökés, s. 214. Hoensch, s. 98 . Janos, s. 202, n. 1.

6. Statspolitiet i Sønderborg, fortrolig rapport 3. maj 1935 ang. politisk virksomhed her i landet udført af tyske emigranter, PADJ 969, Landsarkivet for Sønderjylland.

7. Om Kominterns historie se f.eks. William Z. Foster: History of the Three Internationals. The World Socialist and Communist Movement from 1848 to the Present, 1955, især Part III.

8. Se note 6.

9. Statspolitiet i Aabenraa, rapport 9. maj 1935, PADJ 969, Landsarkivet for Sønderjylland.

10. Statspolitiet i Sønderborg, fortrolig rapport 12. maj 1935, PADJ 969, Landsarkivet for Sønderjylland.

11. S.st.

12. V. Elberling (red.): Avisårbogen 1935, 1936, s. 40-41.

13. Henning Koch: Demokrati - slå til! Statslig nødret, ordenspoliti og frihedsrettigheder 1932-1945, 1994, s. 115, 119-120.

14. E. H.Carr: Twilight of the Comintern 1930-1935, 1982, især Part IIl.

15. Statspolitiet i Aabenraa, rapporter 15. marts 1935, 27. marts 1935 og 3.april 1935, PADJ 969, Landsarkivet for Sønderjylland.

16. Kopi af verbalnoterne i PADJ 969, Landsarkivet for Sønderjylland.

17. Chefen for grænsegendarmeriet til politiadjudanten 6. maj 1935, PADJ 969, Landsarkivet for Sønderjylland.

18. Elberling, s. 119-120, 133. Jfr. Berlingske Tidende 30. april 1935.

19. Rapport til politimesteren i Aabenraa 9. april 1935, PADJ 969, Landsarkivet for Sønderjylland. 
